\title{
ANALISIS FAKTOR INTERNAL DAN LINGKUNGAN KARYAWAN BERKINERJA UNGGUL
}

\section{ANALYSIS OF INTERNAL AND ENVIRONMENTAL FACTORS OF STAR PERFORMER}

\author{
Septi Sawandi Putra*)1, M. Syamsul Maarif', dan Nurmala Katrina Panjaitan**) \\ *) Sekolah Bisnis, IPB University \\ Jl. Raya Pajajaran, Bogor 16151, Indonesia \\ **) Departemen Sains Komunikasi dan Pengembangan Masyarakat, Fakultas Ekologi Manusia, IPB University \\ Kampus IPB Dramaga Bogor, PO Box 220 Bogor 16002, Indonesia
}

\begin{abstract}
PT. XYZ facing a mix performance in their sales team, some of sales person giving stelar achievement, some just pass the standard, and others failed. This study aims to describe the profile of salesperson and to analyze the determinants factors of star performers. Methods of data collection using questionnaires, interviews, observation, literature study, and census techniques (64 salesperson). Data analysis using multiple regression. Salesperson who achieved their annual sales target by the late of November were included in star performers category. Salesperson who reached the sales target in December were categorized as achievers, and those who did not reach the annual target were categorized as not achieving. The results showed that most of the salespeople of PT. XYZ is a male (79.69\%) having a productive age category 38-47 years (35\%), undergraduate education or higher (50\%), a working period of 1-5 years (31.4\%) with a junior sales reps position. sales reps (42.19\%). In 2019, 88,89\% star performers came from PT. XYZ-1, the remaining 11,11\% from PT. XYZ-2, while PT. XYZ 3 and 4 do not have star performers. Factors that affect star performers are competence (communication and adaptability), motivation (need for achievement, resilience) and superiors' supportcoaching and mentoring, Teamwork, creativity, organizational culture and job autonomy do not have a significant effect on superior performing employees.
\end{abstract}

Keywords: motivation, need for achievement, performance, relationships with superior, star performers

\begin{abstract}
Abstrak: PT. XYZ menghadapi kinerja yang beragam dalam tim penjualannya, beberapa staf penjualan memberikan kinerja unggul, beberapa hanya melewati standar, dan lainnya gagal. Penelitian ini bertujuan mendeskripsikan profil tenaga penjual dan menganalisis faktor-faktor penentu karyawan berkinerja unggul. Metode pengumpulan data menggunakan kuesioner, wawancara, observasi, studi pustaka, dan sensus (64 orang tenaga penjual). Analisis data menggunakan regresi berganda. Tenaga penjual yang mencapai target penjualan tahunan paling lambat pada bulan November masuk kategori kinerja unggul. Tenaga penjual yang mencapai target penjualan pada bulan Desember masuk kategori tercapai, dan yang tidak mencapai target tahunan masuk ke dalam kategori tidak mencapai. Hasil penelitian menunjukkan bahwa sebagian besar tenaga penjual PT. XYZ adalah pria $(79,69 \%)$ mempunyai kategori usia produktif 38-47 tahun (35\%), pendidikan S1 atau lebih tinggi (50\%), masa kerja 1-5 tahun $(31,4 \%)$ dengan jabatan junior sales repssales reps $(42,19 \%)$. Pada tahun $2019,88,89 \%$ karyawan berkinerja unggul berasal dari PT.XYZ-1, sisanya11,11\% dari PT.XYZ-2, sementara PT. XYZ 3 dan 4 tidak memiliki karyawan berkinerja unggul. Faktor yang memengaruhi karyawan berkinerja unggul adalah kompetensi (komunikasi dan adaptabilitas), motivasi (need for achievement, daya juang) serta dukungan atasan, dalam hal ini coaching dan mentoring. Kerja sama, kreativitas, budaya organisasi dan otonomi pekerjaan tidak memiliki pengaruh signifikan terhadap karyawan berkinerja unggul.
\end{abstract}

Kata kunci: motivasi, need for achievement, kinerja, hubungan atasan, karyawan berkinerja unggul

${ }^{1}$ Alamat Korespondensi:

Email: ssputra@gmail.com 


\section{PENDAHULUAN}

Sepanjang sejarah peradaban kita telah menyaksikan munculnya manusia-manusia yang unggul di dalam berbagai bidang kehidupan, mulai dari kesenian, olahraga, ilmu pengetahuan, sastra dan berbagai bidang lainnya. Kontribusi mereka jauh melebihi kontribusi rata-rata orang lainnya. Mereka adalah game changer di manapun mereka berada, demikian juga di dalam organisasi. Aoyama et al. (2010) menjelaskan bahwa seperti hukum pareto, 20 persen karyawan berkontribusi dalam 80 persen produktivitas organisasi. Karyawan berkinerja unggul (star performer) konsisten menghasilkan tingkat produktivitas jauh di atas ratarata yang memengaruhi keberhasilan atau kegagalan organisasi dimana mereka berkarya dan bahkan tidak jarang memengaruhi masyarakat secara luas. Selain itu, kehadiran mereka dapat menandakan kebangkitan sebuah organisasi dan ketiadaan mereka dapat menandakan penurunan dan bahkan kematian organisasi (Bedeian dan Armenakis, 1998). Saat ini organisasi memerlukan karyawan berkinerja unggul lebih dari sebelumnya untuk bertahan dan berkembang..

Karyawan berkinerja unggul termotivasi untuk unggul, memiliki ambisi yang luar biasa, dan selalu siap bekerja ekstra untuk maju. Tiap-tiap kesempatan baru dilihat sebagai tantangan untuk ditaklukan (Ready et al. 2010). Bila seseorang termotivasi maka ia akan berupaya sekuat tenaga untuk mencapai tujuan, namun belum tentu upaya yang tinggi akan menghasilkan kinerja yang tinggi. Pada umumnya kinerja yang tinggi dihubungkan dengan motivasi yang tinggi. Sebaliknya, motivasi yang rendah dihubungkan dengan kinerja yang rendah. Motivasi yang diberikan oleh pemimpin kepada karyawan harus bersifat membangun sehingga mampu memajukan suatu organisasi. Diamantidis dan Chatzoglou (2019) menemukan bahwa kemampuan beradaptasi dan motivasi intrinsik hanya berdampak langsung pada kinerja.

MenurutMcCelland(1987)needfor achievement adalah proses pembelajaran yang stabil yang mana kepuasan akan didapatkan dengan berjuang dan memenuhi level tertinggi untuk dapat menjadi ahli dibidang tertentu. David McCelland telah memberikan kontribusi bagi pemahaman motivasi dengan mengidentifikasi tiga macam kebutuhan, yaitu need for Aachievement, need for Ppower, need for affiliation. Need for achievement adalah motif dipelajari yang bertujuan mencapai suatu standar keberhasilan dan keunggulan pribadi di suatu bidang tertentu (Wade dan Tavris, 2008).

Faktor lingkungan dapat meningkatkan kemampuan (katalisator), atau memperkecil kemampuan (insulator) dari karyawan berkinerja unggul (Aguinis et al. 2016). Menurut Whitmore (2003), pembinaan dari atasan dapat dilihat sebagai "membuka potensi seseorang untuk memaksimalkan kinerja mereka sendiri dan itu membantu mereka belajar daripada mengajar mereka". Oleh karena itu, pembinaan adalah prosedur yang memungkinkan individu belajar, meningkatkan keterampilan mereka dan kinerja. Nurheni (2019) menuliskan hubungan dengan atasan dapat meningkatkan job engagement dan kepuasan kerja. Selanjutnya menurut Aguinis et al. (2016) otonomi terhadap pekerjaan dengan kewenangan yang luas dapat membuat karyawan berkinerja unggul bertindak kreatif dan cepat, yang pada akhirnya dapat menjadi katalisator bagi output yang mereka hasilkan. Namun tentu saja ada risiko memiliki karyawan berkinerja unggul dapat menyebabkan ketergantungan yang harus menjadi bahan pertimbangan setiap organisasi (Kehoe dan Tzsabbar, 2015).

Ada banyak penelitian yang menuliskan mengenai teori-teori, faktor-faktor dan peubah mengenai kinerja karyawan hasil pencarian di google cendikia menemukan setidaknya 425.000 jurnal tentang kinerja karyawan, namun hanya bersifat secara umum. Saat ini masih sedikit penelitian yang berfokus pada karyawan berkinerja unggul khususnya di Indonesia. Pencarian di IPB repository, Prasetya Mulya publishing, jurnal. ui.ac.id, serta jurnal.ugm.ac.id mengenai star performer atau karyawan berkinerja unggul tidak ditemukan. Peubah yang jarang dibahas seperti otonomi pekerjaan, kreativitas, kerja sama, adaptabilitas, komunikasi serta peubah populer seperti motivasi, hubungan dengan atasan akan dilihat pengaruhnya pada kinerja karyawan berkinerja unggul dan karyawan biasa.

PT. XYZ adalah perusahaan induk yang bergerak di bidang optik, mulai dari bingkai kacamata, lensa kacamata, lensa kontak, instrumen refraksi hingga retail. Lensa kontak PT. XYZ telah meraih berbagai penghargaan setiap tahunnya mulai dari Top Brand sejak 2011-2019 dan Top Brand for teens 2013-2019, hingga Superbrand tahun 2012-2015. Tahun 2019 hanya lensa kontak yang mencapai target penjualan, sehingga secara global PT. XYZ tidak mencapai target 
penjualan tahun 2019. Tabel 1 menunjukan bahwa $28,12 \%$ tenaga penjual berhasil mencapai taget tahunan sebelum pada bulan September hingga November 2019, 15,6\% mencapai pada bulan desember 2019 dan 56,25\% tidak mencapai target 2019. PT. XYZ memerlukan karyawan dengan performa unggul untuk dapat mencapai dan melebihi target penjualan tahunan dan menjaga posisinya di tengah kompetisi usaha yang semakin keras. Berdasarkan hal ini perlu dilakukan penelitian faktor-faktor penentu karyawan berkinerja unggul dengan tujuan sebagai berikut: (1) Menganalisis pengaruh faktor internal (kompetensi dan motivasi) pada kinerja unggul karyawan, (2) Menganalisis pengaruh faktor lingkungan (budaya organisasi dan dukungan atasan) pada kinerja unggul karyawan, (3) Menganalisis pengaruh faktor internal dan faktor lingkungan pada kinerja ungul karyawan.

\section{METODE PENELITIAN}

Objek yang diteliti adalah kinerja kayawan dari PT. XYZ berlokasi di Jakarta yang bertujuan mengetahui faktor internal dan lingkungan karyawan berkinerja unggul sehingga organisasi dapat menentukan langkah strategis bagi pengembangan karyawan. Pengambilan kuesioner dilakukan di PT XYZ selama satu bulan yaitu mulai dari awal Juli 2020 hingga akhir Juli 2020. Dalam penelitian menggunakan metode kuantitatif dan kualitatif, dimana data kuantitatif diambil dari sebaran kuesioner survei kepada seluruh tenaga penjual PT. XYZ sebagai responden, sensus ini melibatkan 64 orang tenaga penjual dengan menggunakan Google form. Penilaian kinerja unggul berdasarkan pencapaian tenaga penjual pada tahun 2019. Pengumpulan data yang digunakan dalam penelitian ini menggunakan kuesioner yaitu teknik pengambilan data dengan memberikan pertanyaan tertulis kepada responden untuk dijawab sesuai dengan instruksi yang diberikan. Data yang digunakan dalam penelitian ini berupa data kuantitatif, yaitu data yang berbentuk angka atau data kualitatif yang diangkakan (scoring). Skala yang digunakan adalah skala likert, dinyatakan dalam angka mulai dari skala terkecil sampai dengan yang terbesar (skala pengukuran $1-5$ ), sebagai alternatif pilihan jawaban untuk mengukur sikap responden. Data kualitatif dilakukan dengan wawancara mendalam kepada para pimpinan PT. XYZ.

Analisis regresi linear berganda digunakan untuk menemukan faktor-faktor penentu karyawan berkinerja unggul sesuai dengan star performers theory. Karyawan berkinerja unggul ialah individu tidak proposional yang tinggi dan terus-menerus dalam hal (a) kinerja, (b) visibilitas, dan (c) modal sosial yang relevan menurut Call et al. (2015). Istilah tidak proposional karena literatur tidak jelas mengenai tingkat kuantifikasi yang membedakan karyawan berkinerja unggul dari yang lain, sementara terus menerus untuk membedakan antara karyawan berkinerja unggul dengan mereka yang hanya one-hit success menurut Call et al. (2015). Regresi linear berganda memiliki kemampuan untuk melihat signifikansi dari sebuah peubah tidak tetap terhadap peubah tetap, yang dalam hal ini adalah kinerja karyawan. Uji validitas terhadap data primer menunjukan hasil diatas syarat $\mathrm{r}$ 0,2423 untuk 64 responden dengan taraf signifikan 5persen. Hasil uji reliabilitas seluruh peubah memiliki koefisien alpha lebih dari 0,6. Sehingga kuesioner dianggap valid dan pertanyaan reliabel.

KPI dinilai atas pencapaian target penjualan tahunan 2019. Tenaga penjual yang mencapai target penjualan sebelum bulan Desember masuk dalam kategori kinerja unggul, mendapatkan insentif dari perusahaan, bobot y $=3$. Tenaga penjual yang mencapai target 2019 sesuai tenggat waktu yaitu selama bulan Desember masuk dalam kategori tercapai, bobot $\mathrm{y}=2$, dan sisanya yang tidak mencapai target 2019 masuk dalam kategori tidak tercapai, bobot $\mathrm{y}=1$.

Tabel 1. Kinerja tenaga penjual PT. XYZ tahun 2019

\begin{tabular}{lcccccc}
\hline \multirow{2}{*}{ Perusahaan } & \multicolumn{5}{c}{ Pencapaian } \\
\cline { 2 - 7 } & September & Oktober & November & Desember & Tidak tercapai & Total \\
\hline PT. XYZ-1 & 5 & 4 & 7 & 6 & 3 & 25 \\
PT XYZ-2 & & & 2 & 0 & 6 & 8 \\
PT XYZ-3 & & & & 4 & 23 & 27 \\
PT XYZ-4 & & 4 & 9 & & 4 & 4 \\
Total & 5 & 4 & & 36 & 64 \\
\hline
\end{tabular}

Keterangan: PT. XYZ-1 bergerak di bidang lensa kontak, 2 di bidang lensa kacamata, 3 di bidang bingkai kacamata, 4 di bidang instrumen optik. 
Kompetensi seperti kemampuan komunikasi, adaptabilitas dan motivasi pribadi berhubungan erat dengan kinerja unggul. Faktor lingkungan juga dapat menjadi katalisator maupun insulator kinerja unggul. Berdasarkan konsep teori yang telah diuraikan sebelumnya dapat disusun hipotesis penelitian:

H1: Faktor Internal memiliki pengaruh yang postif terhadap karyawan berkinerja unggul.

$\mathrm{H} 2$ : Faktor lingkungan memiliki pengaruh yang positif terhadap karyawan berkinerja unggul.

H3: Faktor internal dan faktor lingkungan bersamasama memiki pengaruh yang positif terhadap karyawan berkinerja unggul
Pengembangan, motivasi dan pelatihan SDM menjadi suatu kewajiban bagi sebuah organisasi di era saat ini, untuk menghasilkan karyawan yang profesional dan berkinerja tinggi. Pengembangan faktor internal, memberikan motivasi yang diperlukan, dukungan dari organisasi dan atasan dapat memberikan dampak terhadap kinerja karyawan. Berikut adalah kerangka penelitian yang disusun oleh penulis. Berdasarkan konsep ini dapat disusun kerangka pemikiran penelitian (Gambar 1) sehingga PT. XYZ sebagai salah satu supplier terbesar kebutuhan optik di Indonesia dapat menghasilkan karyawan berkinerja unggul sebagai bagian dari strategi bisnis untuk menjadi yang terdepan di dalam persaingan bisnis.

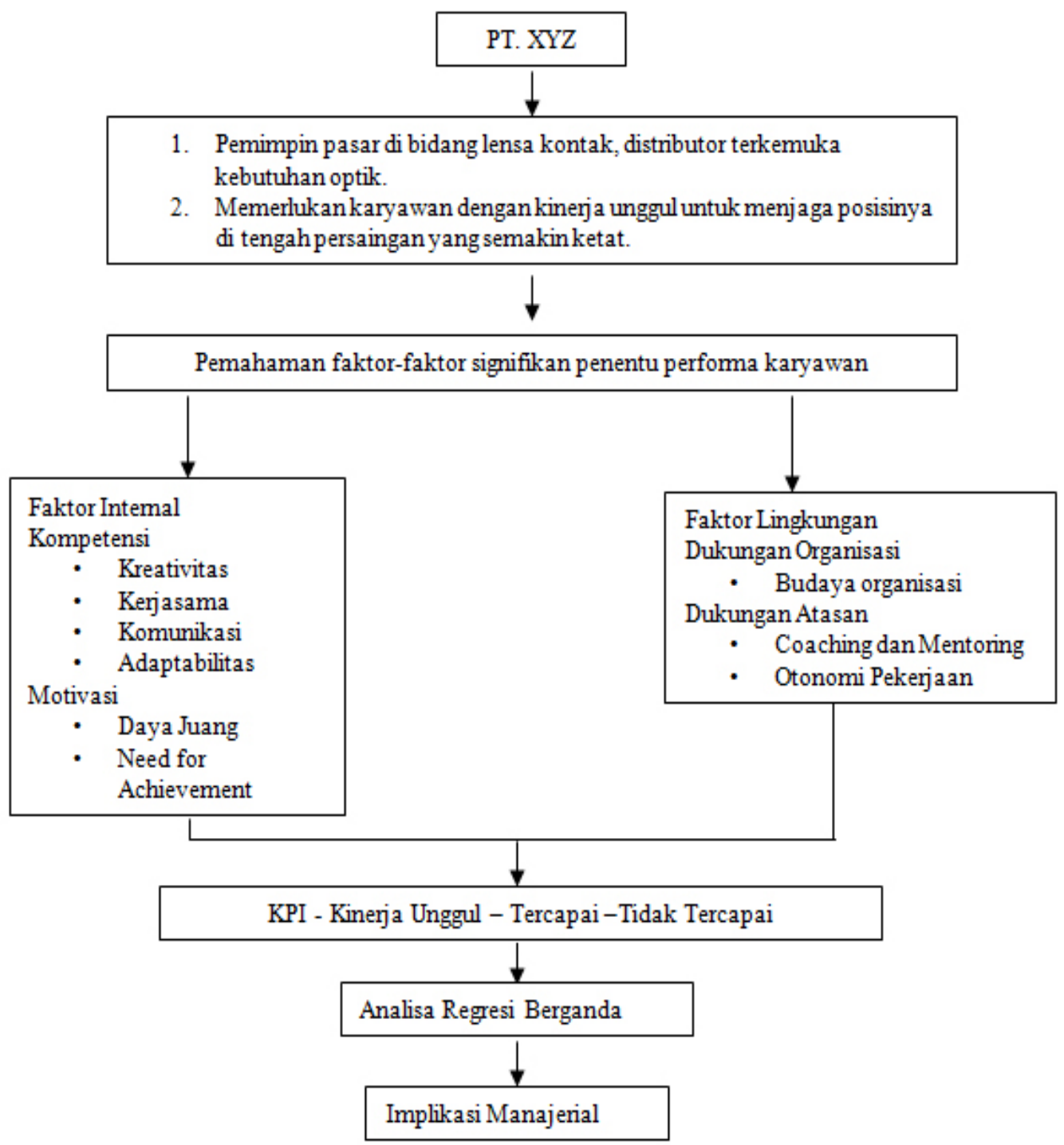

Gambar 1. Kerangka pemikiran penelitian 


\section{HASIL}

\section{Deskripsi Karakteristik Responden}

Karakteristik responden tenaga penjual PT. XYZ berdasarkan isian kuesioner yang telah dilakukan dan data sekunder sebanyak 64 responden, dihasilkan seperti tertera pada Tabel 2 sebagai berikut: 1) jenis kelamin tenaga penjual mayoritas pria sebesar hampir $80 \%$ dan sisanya wanita; 2) Usia $28-37$ tahun mendominasi sebesar $(48,4 \%)$ jika dikaitkan dengan usia kerja, ini merupakan karyawan dengan usia produktif; 3) mayoritas responden memiliki tingkat pendidikan sarjana $(50 \%)$ hal ini menandakan bahwa tenaga penjual memiliki tingkat pengetahuan yang baik; 4) mayoritas responden memiliki masa kerja $1-5$ tahun $(54,7 \%)$, ini menunjukkan masa kerja karyawan yang relatif baru; 5) responden mayoritas menempati stuktur jabatan junior reps hingga sales reps sebesar $(42,2 \%)$ hal ini adalah bentuk umum suatu organisasi dimana SDM terbanyak terletak di bagian bawah struktur organisasi.

Tabel 1. Kinerja tenaga penjual PT. XYZ tahun 2019

\begin{tabular}{lcc}
\hline Keterangan & Jumlah & $\%$ \\
\hline Jenis Kelamin & 51 & 79,7 \\
Pria & 13 & 20,3 \\
Wanita & & \\
Usia & 10 & 15,6 \\
18-27 tahun & 31 & 48,4 \\
28-37 tahun & 20 & 31,3 \\
38-47 tahun & 3 & 4,7 \\
Di atas 48 tahun & & \\
Pendidikan & 29 & 45,3 \\
SMA/sederajat & 3 & 4,7 \\
Diploma & 32 & 50 \\
S1 ke atas & & \\
Masa Kerja & 35 & 54,7 \\
1-5 tahun & 16 & 25 \\
6-10 tahun & 4 & 6,3 \\
11-15 tahun & 4 & 6,3 \\
16-20 tahun & 5 & 7,8 \\
Di atas 21 tahun & & \\
Jabatan & 27 & 42,2 \\
Junior-sales reps & 21 & 32,8 \\
Senior reps- asisten & & \\
manager & 8 & 12,5 \\
Junior manager- area & & \\
manager & & \\
Senior manager ke atas & 8,5 \\
\hline & & \\
\hline & & \\
\hline
\end{tabular}

Komposisi antara pria dan wanita yang bekerja sebagai tenaga penjual di PT. XYZ dapat dikatakan didominasi oleh pria sebesar 4 kali lipat. Pekerjaan tenaga penjual yang harus berkeliling mengunjungi pelanggan masih dianggap kurang cocok untuk ditekuni perempuan, bahkan di lensa kontak yang merupakan pangsa pasar perempuan, hanya ada 1 orang perempuan dari total 25 orang tenaga penjualnya. Milenial dengan rentang usia 18- 37 tahun memiliki komposisi lebih dari $60 \%$ dari tenaga penjual PT. XYZ. Usia muda dapat dikaitkan dengan stamina, tenaga dan waktu luang yang banyak dan optimisme tinggi. Regenerasi di PT. XYZ berjalan dengan baik, fokus perusahaan untuk eksepansi tercermin dalam susunan usia yang bekerja di PT. XYZ yang terdiri dari mayoritas usia muda.

Tingkat pendidikan tenaga penjual di PT. XYZ terbesar adalah S1 atau lebih tinggi 50\% di ikuti oleh SMA/ Sederajat yaitu $45,31 \%$, dan diploma $4,69 \%$. Hal ini dipandang cukup baik dimana mayoritas tenaga penjual di PT. XYZ adalah sarjana, kedepannya manajemen berniat untuk meningkatkan persentase sarjana di tenaga penjual. Pendidikan ahli madya/diploma memang kurang diminati di Indonesia, setelah lulus SMA yang menjadi pilihan utama banyak orang adalah bekerja atau melanjutkan ke Perguruan tinggi strata satu, walau sebenarnya pendidikan diploma memiliki kemampuan yang cukup untuk meniti karir sebagai tenaga penjual. PT XYZ baru berusia 30 tahun, sehingga tidak akan banyak karyawan dengan masa kerja di atas 20 tahun. Sebagai salah satu perusahaan terkemuka dibidang optik, tidak heran banyak karyawan PT XYZ diminati oleh pesaing, tidak sedikit karyawan yang pindah ke perusahaan kompetitor karena mendapatkan tawaran yang lebih baik. Tidak heranjumlah karyawan yang loyal dengan masa kerja di atas 11 tahun jumlahnya hanya 13 orang atau 20,3\%. PT XYZ perlu mempertimbangkan langkah-langkah untuk meningkatkan retensi karyawan, karena karyawan yang berpengalaman dibutuhkan kemampuan dan keterampilannya untuk melasanakan pekerjaan, mengatasi permasalahan yang timbul dengan baik.

\section{Perusahaan dan KPI}

Hasil seperti yang ditunjukan pada Gambar 2, PT. XYZ-1 yang bergerak dibidang lensa kontak memiliki karyawan dengan kinerja unggul dengan persentase terbanyak. Menurut direktur marketing PT. XYZ-1 ini adalah buah investasi bertahun-tahun sebelumnya. Dimana perusahaan telah menginvestasikan banyak 
di bidang pemasaran, dan merekrut tenaga penjual terbaik dari organisasi multinasional, dan hasilnya dapat dirasakan saat ini, dimana kontribusinya dapat dirasakan oleh perusahaan. PT.XYZ-2 ada dua orang yang memiliki kinerja unggul sementara enam orang lainnya tidak tercapai. Sebagai perusahaan yang baru berdiri sejak akhir 2017, perusahaan masih mencari bentuk dan formula yang tepat dalam pemasaran dan penjualan. PT.XYZ-3 memiliki lebih banyak yang tidak mencapai target dibandingkan dengan yang mencapai, hal ini disebabkan karena perusahaan ini kehilangan merek utama bingkai kacamata yang selama bertahun-tahun menjadi produk andalan. Hal ini berdampak pada turunnya nilai penjualan secara drastis dibandingkan tahun-tahun sebelumnya, adapun empat orang yang mencapai target penjualan dapat dipandang sebagai suatu hal yang positif. PT.XYZ-4 yang bergerak dibidang instrumen optik tahun 2019 menghadapi serbuan kompetitor yang menjual instrumen refraksi buatan China dengan harga jauh lebih murah dibandingkan buatan Eropa yang selama ini mereka pasarkan, sehingga perusahaan mengalami penurunan nilai penjualan dan pangsa pasar.

\section{Pengujian Hipotesis}

Pengujian hipotesis bertujuan untuk mengetahui diterima atau ditolaknya hipotesis awal yang telah ditetapkan dengan teori-teori serta hasil penelitianpenelitian sebelumnya. Pengujian hipotesis didasarkan pada hasil penelitian yang dibantu dengan program SPSS Statistik 21.Pengujian hipotesis meliputi uji korelasi, koefisien determinasi, uji simultan dan uji parsial.

\section{Uji R (Koefisien Korelasi)}

Korelasi merupakan suatu Teknik Statistik yang dipergunakan untuk mengukur kekuatan hubungan dua Peubah dan juga untuk dapat mengetahui bentuk hubungan antara dua Peubah. Koefisien korelasi (R) memiliki nilai antara -1.00 hingga +1.00 . Semakin $R$ mendekati angka 1.00 maka dapat diartikan hubungan antar variabel bebas dengan variabel terikat semakin kuat. Nilai Uji R penelitian ini adalah 0,815 (81,5\%) yang berarti bahwa peubah-peubah dalam penelitian memiliki korelasi positif (korelasi linear positif) sebesar $81,5 \%$.

\section{Uji $\mathbf{R}^{2}$ (Koefisien Determinasi)}

Koefisien determinasi digunakan untuk mengetahui seberapa besar hubungan dari beberapa peubah dalam pengertian yang lebih jelas. Koefisien determinasi akan menjelaskan seberapa besar perubahan atau variasi suatu peubah bisa dijelaskan oleh perubahan atau variasi pada peubah yang lain (Ghozali, 2012). Nilai koefisien ini antara 0 dan 1, jika hasil lebih mendekati angka 0 berarti kemampuan peubah-peubah independen dalam menjelaskan variasi peubah amat terbatas. Tapi jika hasil mendekati angka 1 berarti peubah-peubah independen memberikan hampir semua informasi yang dibutuhkan untuk memprediksi variasi peubah dependen.

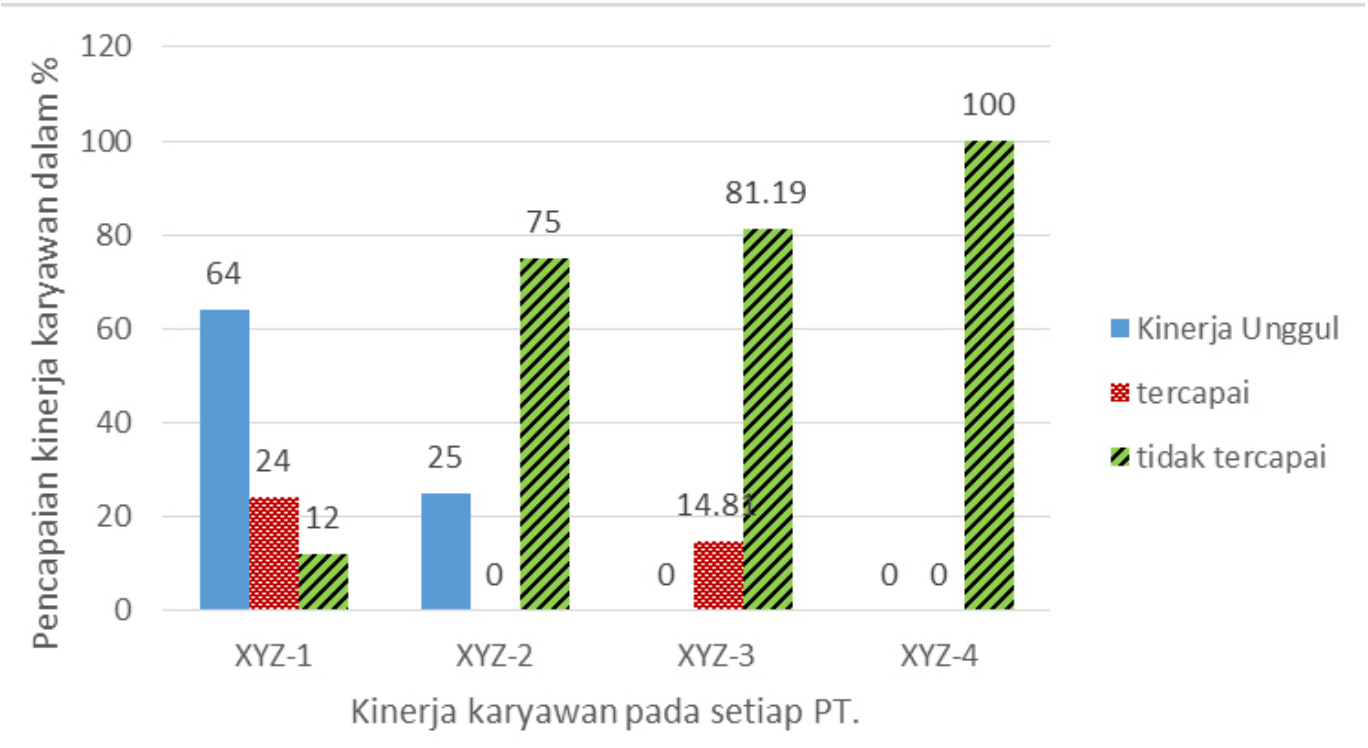

Gambar 2. Perusahaan dengan kinerja 
Dari hasil pengujian $\mathrm{R}^{2}$ yang telah dilakukan, diperoleh hasil Adjusted R-Square sebesar 0,647 (64,7\%). Dengan ini dapat disimpulkan bahwa peubah dependen kinerja karyawan unggul dapat dijelaskan oleh perubahan dari peubah-peubah independen yaitu faktor internal dan faktor lingkungan sebesar $64,7 \%$. Sisanya sebesar 35,3\% dipengaruhi peubah lain yang tidak diikutsertakan dalam penelitian.

\section{Pengaruh Faktor Internal Terhadap Kinerja Karyawan Unggul}

Faktor internal yang diduga berpengaruh terhadap kinerja unggul terdiri dari: (1) kompetensi (komunikasi, kerjasama, kreativitas, adaptabilitas) dan (2) motivasi (need for achievement, daya juang). Hasil analisis koefisien Pearson correlation, nilai koefisien korelasi antara faktor internal yaitu kompetensi dan motivasi dengan kinerja unggul di PT. XYZ disajikan pada Tabel 3. Berdasarkan analisis koefisien Pearson correlation, nilai koefisien korelasi antara kompetensi $(0,471)$ dan motivasi $(0,430)$ dengan kinerja unggul. Menurut tabel interpretasi koefisien korelasi (Sugiyono 2007), nilai koefisien korelasi hubungan antara faktor internal (kompetensi dan motivasi) dengan kinerja unggul berada pada kategori hubungan cukup kuat, yaitu antara 0.40-0.599.

Tabel 3. Hubungan faktor internal dengan KPI

\begin{tabular}{lcc}
\hline \multirow{2}{*}{\multicolumn{1}{c}{ Faktor Internal }} & \multicolumn{2}{c}{ KPI (Y) } \\
\cline { 2 - 3 } & $\begin{array}{c}\text { Nilai } \\
\text { Korelasi rs }\end{array}$ & P Value \\
\hline Kompetensi &, $471^{* *}$ & 0,000 \\
Komunikasi (X1.1.1) &, $536^{* *}$ & 0,000 \\
Kerjasama (X1.1.2) & 0,076 & 0,553 \\
Kreativitas (X1.1.3) & 0,082 & 0,519 \\
Adaptabilitas (X1.1.4) &, $454^{* *}$ & 0,000 \\
Motivasi &, $430^{* *}$ & 0,008 \\
Need for Achiement (X1.2.1) &, $637^{* *}$ & 0,000 \\
Daya Juang (X1.2.2) &,$- 586^{* *}$ & 0,000 \\
\hline Keterangan: &
\end{tabular}

Keterangan: ** Berhubungan nyata $(\mathrm{p}$-value $<0,01)$

Terdapat hubungan yang nyata antara motivasi dengan kinerja unggul dalam penelitian ini mencerminkan terdapat hubungan yang erat antara motivasi dengan kinerja unggul. Hal ini sesuai dengan pendapat Budiharjo (2020), Ezarik (2018), dan Ready et al. (2010) yang mengatakan bahwa salah satu faktor yang diduga memengaruhi kinerja unggul seseorang adalah motivasi kerjanya. Hubungan yang nyata antara kompetensi dan kinerja unggul juga sesuai dengan pendapat Armstrong dan Baron (1998), Ready et al. (2010), dan Pulakos et al. (2002), yang mengatakan bahwa salah satu faktor yang diduga memengaruhi kinerja unggul seseorang adalah kompetensinya.

Sejalan dengan Pulakos et al. (2002) penelitian ini menemukan bahwa adaptabilitas memiliki nilai koefisien korelasi dengan kinerja unggul cukup kuat $(0,454)$. Adaptasi merupakan salah satu faktor penting tidak hanya bagi kinerja unggul melainkan bagi evolusi mahluk hidup. Di masa kini pekerja dituntut untuk dapat beradaptasi sesuai tuntutan perkembangan jaman. Komunikasi juga memiliki nilai koefisien korelasi dengan kinerja unggul cukup kuat $(0,536)$, hal ini sesuai dengan pendapat Budiharjo (2020), Ezarik (2018). Komunikasi adalah fondasi dalam setiap hubungan intra personal, komunikasi yang baik akan membantu tenaga penjual dalam mencapai kesepakatan penjualan.

Penelitian ini menemukan analisis koefisien Pearson correlation, nilai koefisien korelasi antara kerjasama $(0,076)$ dengan kinerja unggul yang sangat lemah $(0,000-0,190)$ berbeda dengan pendapat Burn (2004), Froebel dan Marchington (2005), dan Harris (2008) hal ini mungkin disebabkan karena mayoritas tenaga kerja di PT. XYZ adalah milenial, dan menurut Moore (2005) milenial lebih bersikap individual sehingga faktor kerjasama buka menjadi hal yang penting bagi mereka. Penelitian ini juga menemukan analisis koefisien Pearson correlation, nilai koefisien korelasi antara kreativitas $(0,082)$ dengan kinerja unggul yang sangat lemah $(0,000-0,190)$ berbeda dengan pendapat Budiharjo (2020) dan Ready et al. (2010), hal ini mungkin karena responden pada penelitian ini hanya tenaga penjual, jika ruang lingkupnya diperbesar hingga seluruh karyawan, mungkin saja hasilnya berbeda. Selain itu, PT. XYZ memiliki divisi marketing yang terpisah dari divisi sales. Divisi marketing ini memiliki tugas soft selling, branding, komunikasi marketing, dan kerja kreatif lainnya, sehingga tenaga penjual tidak perlu untuk berfikir kreatif dalam menjual produk.

Hasil uji hipotesis ini menunjukkan nilai signifikan sebesar 0,01. Berdasarkan perbandingan tingkat signifikan hasil uji hipotesis dengan tingkat signifikan yang ditetapkan yaitu 0,05 , maka hasil uji hipotesis 1 yaitu $0,01<0,05$. Hal ini berarti $\mathrm{H}_{1}$ diterima dan $\mathrm{H}_{0}$ ditolak, dengan demikian faktor internal berpengaruh secara signifikan terhadap kinerja karyawan unggul. 


\section{Pengaruh Faktor Lingkungan Terhadap Kinerja Karyawan}

Faktor lingkungan yang diduga berpengaruh terhadap kinerja unggul terdiri dari: (1) dukungan organisasi (budaya organisasi) dan (2) dukungan atasan (coaching dan mentoring, otonomi pekerjaan). Hasil analisis koefisien Pearson correlation, nilai koefisien korelasi antara faktor lingkungan dengan kinerja unggul di PT. XYZ disajikan pada Tabel 4. Dalam hal dukungan organisasi, penelitian ini menemukan analisis koefisien Pearson correlation, nilai koefisien korelasi antara dukungan organisasi $(-0,149)$ dengan kinerja unggul yang sangat lemah $(0,000-0,190)$ berbeda dengan pendapat Brahmawati (2008), hal ini mungkin disebabkan karena budaya organisasi di PT. XYZ adalah belum dikomunikasikan, dan diterapkan secara baik, sehingga karyawan tidak melihat atau merasakan manfaat dari budaya organisasi tersebut.

Tabel 4. Hubungan faktor lingkungan dengan KPI

\begin{tabular}{lcc}
\hline \multirow{2}{*}{\multicolumn{1}{c}{ Faktor Lingkungan }} & \multicolumn{2}{c}{ KPI (Y) } \\
\cline { 2 - 3 } & $\begin{array}{c}\text { Nilai } \\
\text { Korelasi rs }\end{array}$ & P Value \\
\hline Dukungan Organisasi & $-0,149$ & 0,238 \\
Budaya Organisasi (X2.1.1) & $-0,149$ & 0,238 \\
Dukungan Atasan &, $635^{* *}$ & 0,000 \\
Coaching dan Mentoring &, $738^{* *}$ & 0,000 \\
(X2.2.1) & & \\
Otonomi Pekerjaan (X2.2.2) & 0,004 & 0,975 \\
\hline
\end{tabular}

Keterangan: ** Berhubungan nyata ( $\mathrm{p}$-value $<0,01$ )

Dukungan atasan memiliki nilai koefisien korelasi $(0,635)$, coaching dan mentoring memiliki nilai koefisien korelasi $(0,738)$, dengan kinerja unggul. Menurut tabel interpretasi koefisien korelasi (Sugiyono 2007), nilai ini menunjukkan korelasi antar peubah kuat, yaitu antara 0.600-0.799 hal ini sesuai dengan pendapat Kumar et al. (2018) bahwa atasan memiliki pengaruh penting dalam kinerja unggul bagi seorang tenaga penjual dalam mencapai target mereka.

Otonomi pekerjaan dianggap memiliki pengaruh terhadap kinerja unggul menurut Aguinis et al. (2016) dan Knight (2017) namun hasil penelitian ini menunjukkan berbeda. Analisis koefisien Pearson correlation, nilai koefisien korelasi antara otonomi pekerjaan $(0,004)$ dengan kinerja unggul yang sangat lemah $(0,000-0,190)$. Perbedaan budaya antara barat dan timur mungkin berpengaruh, sehingga di Indonesia, khususnya di PT. XYZ otonomi pekerjaan dianggap tidak penting, setidaknya untuk saat ini.

Hasil uji hipotesis ini menunjukkan nilai signifikan sebesar 0,00. Berdasarkan perbandingan tingkat signifikan hasil uji hipotesis dengan tingkat signifikan yang ditetapkan yaitu 0,05 maka hasil uji hipotesis 2 yaitu $0,00<0,05$. Hal ini berarti $\mathrm{H}_{2}$ diterima dan $\mathrm{H}_{0}$ ditolak, dengan demikian peubah faktor lingkungan berpengaruh secara signifikan terhadap kinerja karyawan unggul di PT XYZ.

\section{Pengaruh Faktor Internal dan Faktor Lingkungan Terhadap Kinerja Karyawan}

Penelitian ini melalui uji $\mathrm{F}$ menemukan bahwa faktor internal dan faktor lingkungan memiliki pengaruh yang signifikan terhadap kinerja karyawan unggul pada PT XYZ. Dengan diperoleh nilai $F_{\text {hitung }}$ sebesar 39,472 dengan nilai probabilitas $(\mathrm{sig})=0,000$ lebih besar dari nilai $\mathrm{F}_{\text {tabel }} 2,06$ dan nilai sig. lebih kecil dari nilai probabilitas 0,05 atau nilai $0,000<0,05$; maka $\mathrm{H}_{1}$ diterima, berarti secara bersama-sama (simultan) peubah Faktor Internal dan Faktor Lingkungan berpengaruh terhadap kinerja karyawan unggul di PT XYZ.

Analisis korelasi bertujuan untuk mengetahui ada atau tidaknya hubungan antara dua variabel atau lebih, dalam hal ini faktor internal dan faktor lingkungan terhadap KPI. Selanjutnya dilakukan uji t untuk memprediksi seberapa jauh pengaruh yang ada tersebut. Uji statistik $\mathrm{t}$ pada dasarnya bertujuan untuk menunjukkan seberapa jauh pengaruh satu peubah independen dalam menerangkan variasi peubah dependen. Oleh karena itu, untuk mengetahui pengaruh peubah independen terhadap peubah dependen secara parsial dapat dilihat dari besarnya nilai $\mathrm{t}$ dan sig (signifikan). Nilai $\mathrm{t}_{\text {tabel }}$ adalah 2,00404. Hasil Stepwise ke tiga menunjukkan bahwa ada tiga peubah yang terpilih dengan nilai $t_{\text {hitung }}>$ 2,00404, yaitu peubah hubungan atasan coaching dan mentoring $(5,067)$, Motivasi Need for Achievement $(3,296)$, dan daya juang $(-2,327)$. Ketiga peubah tersebut juga memiliki nilai signifikansi dibawah 0,05 $($ sig $<0,05)$.

\footnotetext{
KINERJA UNGGUL $=\mathbf{- 0 , 5 1 7}+$ $1,370 *$ CoachingMentoring + $0,662 *$ NeedForAchievement $-0,8 *$ DayaJuang
} 


\section{Implikasi Manajerial}

Hasil penelitian yang mencakup faktor internal dan faktor lingkungan, maka dapat disampaikan implementasi manajerial yang terbagi menjadi lima butir, yaitu (1) Hubungan dengan atasan memilki nilai koefisien Pearson 0.738, memiliki hubungan kuat terhadap kinerja unggul. Perusahaan harus memandang penting memiliki atasan mulai dari tingkat penyelia hingga senior manager yang kompeten mulai dari proses rekrutment hingga training berkala bagi atasan.Memilih supervisor/manager yang kompeten jika posisi tersebut kosong. (2) Perusahaan harus mampu memotivasi setiap individu, dalam setiap keadaan. Organisasi harus mampu menumbuhkan kesadaran setiap tenaga kerja untuk berprestasi dan juga memberikan penghargaan yang sepadan atas pencapaiaan mereka.

Budaya organisasi menjadi peubah yang tidak berpengaruh signifikan, hal ini berarti karyawan tidak merasakan pentingnya budaya organisasi, atau budaya organisasi belum dikomunikasikan dengan baik secara terus menerus kepada karyawan. Budaya organisasi adalah identitas dan pembeda atara suatu organisasi dengan organisasi lainnya. Penting bagi PT. $\mathrm{XYZ}$ untuk dapat memperkuat budaya organisasi dan mengkomunikasikannya kepada seluruh karyawan. Perusahaan juga perlu memberikan pelatihan bagi karyawan secara berkala untuk dapat berkomunikasi baik lisan maupun non lisan, langsung maupun secara daring. Perlu dilakukan simulasi dan membuat buku panduan untuk menjawab keberatan-keberatan yang biasa ditemukan di lapangan.

\section{KESIMPULAN DAN SARAN}

\section{Kesimpulan}

Hasil Penelitian dilakukan dengan metode kuantitatif melalui penyebaran kuesioner yang akan disebar kepada para tenaga penjual PT. XYZ sebanyak 64 orang atau responden. Sebagian besar karyawan berkinerja unggul di PT XYZ berasal dari PT. XYZ-1. Hal ini menandakan bahwa banyak karyawan belum menunjukkan kinerja terbaik mereka, dan PT XYZ-2 hingga XYZ-4 perlu mereplikasi cara kerja tenaga penjual di PT. XYZ-1 agar dapat memiliki output serupa.

Faktor internal dalam hal ini kompetensi (komunikasi, adaptabilitas) dan motivasi (need for achievement, daya juang) memiliki korelasi cukup kuat dengan terhadap karyawan berkinerja unggul, sementara kerjasama, kreativitas tidak berpengaruh terhadap kinerja unggul. Faktor lingkungan dalam hal ini hubungan atasan (coaching-mentoring) memiliki korelasi kuat dengan terhadap karyawan berkinerja unggul, sementara budaya organisasi dan otonomi pekerjaan tidak berpengaruh terhadap kinerja unggul.Hasil uji $\mathrm{F}$ menunjukkan secara bersama-sama (simultan) peubah Faktor Internal dan Faktor Lingkungan berpengaruh terhadap kinerja karyawan unggul di PT XYZ.

\section{Saran}

Terdapat beberapa hal yang dapat disarankan oleh penulis sehubungan dengan pembahasan mengenai pengaruh peubah faktor internal dan lingkungan terhadap kinerja karyawan unggul di PT XYZ. Hubungan dengan atasan memiliki peranan penting, perusahaan perlu memperlengkapi level manager ke atas dengan kemampuan coaching dan mentoring untuk dapat membina dengan baik staf yang menjadi tanggung jawabnya. Perusahaan juga perlu untuk meningkatkan kemampuan komunikasi setiap tenaga penjualnya. Tenaga penjual yang hebat di masa kini tidak hanya dituntut untuk pandai berbicara, melainkan juga harus cerdas dalam mendengarkan dan mengajukan pertanyaan yang dapat menuntun pada suksesnya proses penjualan.

Perlu diberikan penghargaan yang sesuai dengan prestasi yang diberikan kepada perusahaan. Bentukbentuk penghargaan tidak harus berupa uang, namun juga berupa pujian yang proporsional dengan prestasi sehingga karyawan dapat terus terpacu dalam bekerja. Bentuk penghargaan lain dapat diberikan berupa pemberian kesempatan mengembangkan diri melalui pendidikan formal maupun informal sehingga karyawan terus berkembang yang pada akhirnya diharapkan dapat meningkatkan kinerja kerja karyawan dan akan menjadi nilai tambah bagi karyawan yang bersangkutan serta bagi perusahaan tersebut.

\section{DAFTAR PUSTAKA}

Aguinis H, O'Boyle E, Gonzalez-Mulé E, dan Joo H. 2016. Cumulative advantage: Conductors and insulators of heavy-tailed productivity distributions and productivity stars. Personnel Psychology 69(1): 3-66 
Aoyama H, Yoshikawa H, Iyetomi H, Fujiwara Y. 2010. Productivity dispersion: facts, theory, and implications. Journal of economic interaction and coordination 5(1): 27-54.

Armstrong M, Baron A. 1998. Performance Management - The New Realities. London: Institute of Personnel and Development.

Bedeian AG, Armenakis AA. 1998. The cesspool syndrome: How dreck floats to the top of declining organizations. Academyof Management Perspectives 12(1): 58-63.

Brahmasari IA. 2008. Pengaruh budaya organisasi dan motivasi kerja terhadap komitmen karyawan dan kinerja perusahaan. Jurnal Ilmu Ekonomi dan Manajaemen 5(1): 167-200

Budihardjo A. 2020. Teknologi dan MSDM. Forum Manajemen 33(4): 2-5

Burn SM. 2004. Groups Theory and Practice. Kanada: Thomson dan Wadsworth.

Call ML, Nyberg AJ, Thatcher S. 2015. Stargazing: An integrative conceptual review, theoretical reconciliation, and extension for star employee research. Journal of Applied Psychology 100(3): 623-640.

Diamantidis AD, Chatzoglou P. 2019. Factors affecting employee performance: an empirical approach. International Journal of Productivity and Performance Management 68(1): 171-193.

Ezarik, M. 2018. Top 10 traits of the most talented employees. https://www.chase.com/ news/101216-top-talent [4 Apr 2020].

Froebel P, Marchington M. 2005. Teamwork structures and worker perception: a cross national study in pharmaceuticals. International Journal of Human Resource Management 16(2): 256-276

Ghozali I, Ratmono D. 2017 Analisis Multivariat dan Ekonometrika (Teori, Konsep, dan Aplikasi dengan Eviews 10). Semarang: Badan Penerbit Universitas Diponergoro.
Harris CM, Mcmahan GC. 2008. An Empirical InvestigationOfHumanCapitalAndPerformance: Ncaa Men's Basketball Teams. In: Academy of Management Proceedings. Briarcliff Manor, NY 10510: Academy of Management 2008 (1): 1-6.

Kehoe RR, Tzabbar D. 2015. Lighting the way or stealing the shine? An examination of the duality in star scientists' effects on firm innovative performance. Strategic Management Journal 36(5): 709-727.

Knight R, 2017. How To Manage Your Star. https:// hbr.org/2017/06/how-to-manage-your-staremployee\#comment-section [4 Apr 2020].

Kumar V, Goreczny A, Maurer T. 2018. What drives a salesperson's goal achievement? An empirical examination. Journal of Business dan Industrial Marketing 33(1): 3-18

McClelland DC. 1987. Characteristics of Successful Entrepreneurs. The Journal of Creative Behavior 21:219-233.

Moore RL. 2005. Generation ku: Individualism and China's millennial youth. Ethnology 44(4): 357376.

Nurheni N, Sukmawati A, Dirdjosuparto S. 2019. Pengaruh kualitas kehidupan kerja dan kepuasan kerja terhadap keterlekatan karyawan generasi X dan generasi Y pada PT. Yudhistira Ghalia Indonesia. Jurnal Aplikasi Bisnis Dan Manajemen (JABM) 5(3): 419- 429. https://doi. org/10.17358/jabm.5.3.419.

PulakosEDetal.2002.Predicting adaptiveperformance: further tests of a model of adaptability. Human Performance 15(4): 299-323..

Ready DA, Conger JA, Hill LA. 2010. Are you a high potential. Harvard Business Review 88(6): 7884

Sugiyono. 2007. Metode Penelitian Administrasi. Bandung: Alfabeta.

Wade C, Tavris C. 2007. Psikologi, Edisi ke -9 jilid 2. Jakarta: Erlangga. 